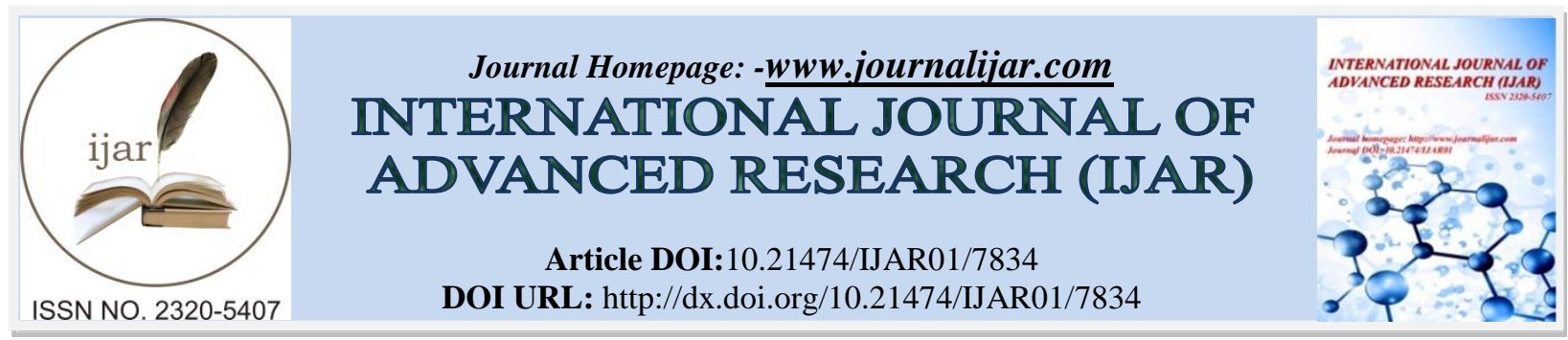

RESEARCH ARTICLE

\title{
DEVELOPMENT OF A CLOSED PRODUCTION PROCESS OF TAPIOCA INDUSTRY.
}

Tajuddin Bantacut and Fiona Arintika Ramadhani.

Departement of Agroindustrial Technology Bogor Agricultural University Indonesia.

\section{Manuscript Info}

Manuscript History

Received: 7 August 2018

Final Accepted: 9 September 2018

Published: October 2018

Keywords:-

energy independent, closed system, mass balance, tapioca industry.

\begin{abstract}
Tapioca production consumes large amount of energy to process cassava into tapioca. Most energy used is fossil energy in the form of electricity and diesel oil which availability has declined so that affect the tapioca production process in the very near future. In addition to producing main products, tapioca industry also generates certain amount of by-products such as cassava's peel, stockpile and wastewater that potentially be utilized as an energy source. This research aimed to develop a model of a closed system of energy independent production process of tapioca through reusing the by-product as the energy source. Development of a closed system model was based on the mass balance, assessing energy content of by-products, and build a closed system of tapioca production process. This study used secondary data of processing stages and primary data of material balance from a tapioca industry. The results showed that the achievable yield of tapioca was $32 \%$. The tapioca industry with 1,000 ton of cassava per day has the potential energy of $1,407,714,408 \mathrm{kcal}$ per day derived from cassava stockpiles and cassava peels. This potential energy is able to meet the energy requirements of 99,261 kWh per day for the production process. Therefore, the tapioca industry is potentially being an energy independent industry by optimizing the utilization of by-products.
\end{abstract}

Copy Right, IJAR, 2018,. All rights reserved.

\section{Introduction:-}

The tapioca industry that process cassava always generates by-products in the form of solid waste (stockpile) as much as 16.5\%, cassava peel (10-15\%), and wastewater (Grace 1997, Kosugi et al. 2008). Mareta (2010) and Winarno et al. (1988) find that the content of carbohydrates in the stockpile is $68 \%$ and in the crude fiber is $10 \%$. Mareta (2010) states that the number of stockpiles produced from tapioca production process ranges from 5-10\% of the weight of the raw material. Without a proper handling, these by-products can cause environmental pollution. In general, this industry only produces tapioca at $20-30 \%$ of the weight of processed cassava (Rahmatul 2013). Stockpile and peel are potential to be used as energy sources to produce heat of the drying process of cassava starch. The tapioca production process will continue to grow to meet the growing demand for both industrial raw materials and food ingredients. Sriroth et al. (2000) calculated the normal needs of electrical energy and thermal energy for producing one $\mathrm{kg}$ of tapioca is about $0.320-0.939 \mathrm{MJ}$ and $1.141-2.749 \mathrm{MJ}$ respectively or $25 \%$ in the form of electrical energy and $75 \%$ in the form of heat and still use energy derived from diesel oil.

A closed system is a system that is not related to and not affected by the environment outside the system. In the production process, a closed system can be interpreted as mass and energy balance that is integrated only with the 
flow of material in the system. Closed systems are not related to mass and energy flows from and to the outside of the system (Cengel and Boles 2002). The closed system can be applied to all industries that process agricultural products containing carbohydrates, fiber, oil and fat. Examples of these industries are crude palm oil (Bantacut and Pasaribu 2015), sugar mills (Bantacut and Novitasari 2016), rice mills (Bantacut and Nurdiansyah 2017), corn processing (Bantacut and Zuriel 2018), peanut processing, tapioca and others.

This opinion shows that the tapioca industry can meet its energy needs through processing its by-products. The byproducts processing can be done to build a closed system without energy input from outside the production system. The purpose of this study was to develop a closed tapioca production process model using the principle of mass and energy balance. To meet this goal the following steps need to be done:

1. Calculating mass balance in the tapioca production process

2. Calculating the energy needed in the tapioca production process

3. Design and develop process flow models for energy independent tapioca industries

\section{Method:-}

\section{Scope of the Research}

This research is limited to the production process of tapioca from cassava and produces cassava peel, wastewater, and piles. Analysis to develop a model was carried out on the transfer of mass flow in and out, loss during, and energy use for the production process, and analysis of the energy potential of the by-products. The results of the model were compared with actual factory data to determine the level of accuracy. The actual data obtained is based on the tapioca production process of the capacity of 1,000 tons of cassava per day.

\section{Type and Source of Data}

The data used were primary and secondary data. Primary data onto a factory were obtained from direct observation of the production process at a tapioca factory in Lampung (Southern Sumatera, Indonesia). Secondary data was obtained from literature studies in the form of books, journals, theses, electronic articles and other scientific articles.

\section{System Boundary}

The tapioca flour production process consists of five main compartments namely stripping station, size reduction (grating) station, extraction station, drying station, and milling station. The main input are 1,000 tons cassava per day and water. The main products are tapioca flour and by-products in the form of cassava peel, wastewater, piles and steam. Cassava peel and wastewater are the output of the first compartment (the stripping station), the pile is the output of the third compartment (the extraction station), and water vapor is the output of the fourth compartment (the drying station).

\section{Model Description}

Mass balance models were developed based on mass flows that describe the real production process. These models connect inputs as independent variables and outputs as dependent variables using the ratio (efficiency coefficient) of both based on the principle of linear equations. The calculation tool used was Microsoft Excel. The flow of tapioca production capacity of 1,000 ton of cassava per day was used as the reference. Calculation results from the model were compared with the real data onto tapioca processing industry in Lampung, then used to calculate the potential amount of energy from by-products as alternative energy sources to meet the needs of the production process. Model that has a high level of accuracy and in accordance with the real production process were used as a basis for calculating energy potential from the by-products to develop an independent energy tapioca production process model.

\section{Mass Balance Model and By-product Energy Content}

Modeling mass balances started by identifying compartments to describe the production process, then the model was formed into the mass balance equation that connects inputs (cassava and additional materials) and output (tapioca). The by-products are wastes that were assumed to be recovered. Secondary data onto mass flows of tapioca production process were used to find efficiency equations. After the mass balance equation and efficiency can be formed, the value of the efficiency factor and the mass balance was determined. The proposed models consist of two type that are simple and complex models.

The equation below was used to calculate by-product energy potential: Energy potency $(\mathrm{kcal})=$ Mass $(\mathrm{kg}) \times$ Calorific value $(\mathrm{kcal} / \mathrm{kg})$ 
The calorific value was obtained from the literature and mass of the by-products was calculated using the mass balance model.

\section{Simple Model}

The simple model assumes that all process stages in one single compartment. This model explains the total number of inputs and outputs in the system only in general (Figure 1).

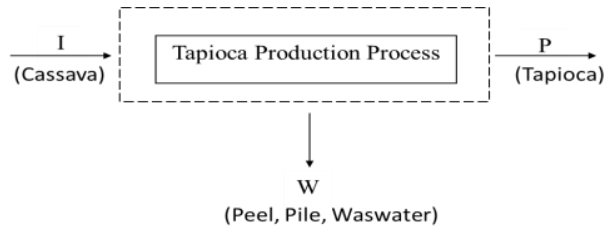

Figure 1:-Simple model of tapioca processing

Notes: $\mathrm{I}=$ input, $\mathrm{P}=$ product, $\mathrm{W}=$ waste $\mathrm{I}=\mathrm{P}+\mathrm{W}$

Mass balance equation is made by assuming the input is equal to output. The expected process efficiency is close to $100 \%$, that is, all mass flows in the conversion process can be known, identified and calculated. The equation that describes a mass balance is:

$$
\text { Efisiensi }(a)=\frac{P}{I}
$$

Where (a) is the ratio which value is between 0 to 1

\section{Complex Model}

\section{Process and Material Flows}

The complex mass balance model consists of independent variables as mass inputs and dependent variables as the output of the process. This model has 21 variables consisting of 5 independent variables $\left(\mathrm{I}_{11}, \mathrm{I}_{12}, \mathrm{I}_{41}, \mathrm{I}_{51}\right.$, and $\left.\mathrm{I}_{61}\right)$ and 16 dependent variables $\left(\mathrm{X}_{1}, \mathrm{X}_{2}, \mathrm{X}_{3}, \mathrm{X}_{21}, \mathrm{X}_{4}, \mathrm{X}_{5}, \mathrm{X}_{6}, \mathrm{X}_{7}, \mathrm{P}_{91}\right.$; and $\mathrm{W}_{11}$ to $\left.\mathrm{W}_{81}\right)$. Dependent variable $\mathrm{X}_{8}$ can be ignored, because it acts as explanations of the flow of the production process. The process at the sifting station is a direct flow, so there is no flow out of the system (Figure 2).

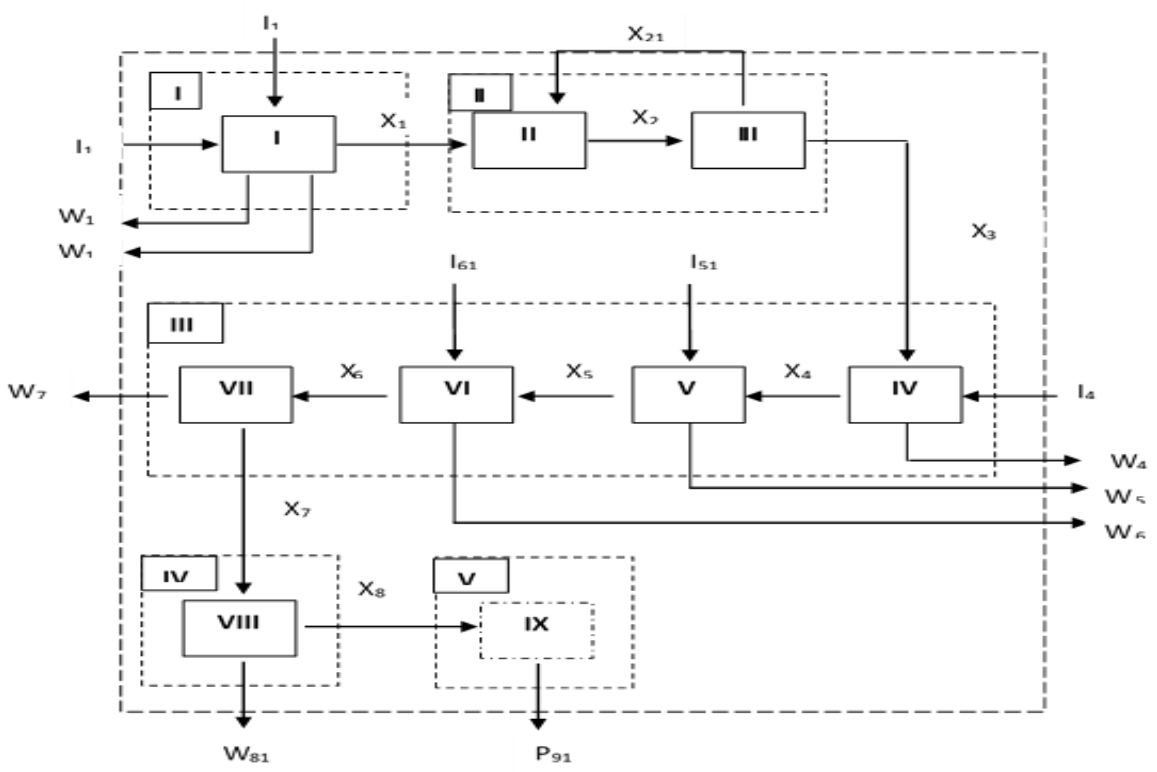

Figure 2:-Complex model of mass balance of tapioca production (see Table 1 and 2 for symbols explanation) (Notes: Compartment IX is neglected bacause very small mass flow out of it). 
Table 1:-Compartment in tapioca production

\begin{tabular}{|l|l|l|}
\hline Stasiun & Compartment & Explanation \\
\hline 1 & I & Peeling \\
\hline 2 & II & Grating \\
\hline & III & Rasping \\
\hline 3 & IV & Extractor 1 \\
\hline & V & Extractor 2 \\
\hline & VI & Separator \\
\hline 4 & VII & Dewatering \\
\hline 5 & VIII & Drying \\
\hline & IX & Sifting \\
\hline
\end{tabular}

Table 2:-Variable symbols explanation

\begin{tabular}{|c|c|}
\hline Symbol & Explanation \\
\hline $\mathrm{I}_{11}$ & Whole Cassava \\
\hline $\mathrm{I}_{12}$ & Water \\
\hline $\mathrm{I}_{41}$ & Water \\
\hline $\mathrm{I}_{51}$ & Water \\
\hline $\mathrm{I}_{61}$ & Water \\
\hline $\mathrm{X}_{1}$ & Peeled cassava \\
\hline $\mathrm{X}_{2}$ & Grated cassava \\
\hline $\mathrm{X}_{3}$ & Rasped cassava \\
\hline $\mathrm{X}_{21}$ & Scattered cassava \\
\hline $\mathrm{X}_{4}$ & $1^{\text {st }}$ extraction of cassava pulp \\
\hline $\mathrm{X}_{5}$ & $2^{\text {nd }}$ extraction of cassava pulp \\
\hline $\mathrm{X}_{6}$ & Cassava slurry results from separation \\
\hline$X_{7}$ & Wet Starch \\
\hline $\mathrm{X}_{8}$ & Rough Tapioca \\
\hline $\mathrm{W}_{11}$ & Cassava peel \\
\hline $\mathrm{W}_{12}$ & Wastewater \\
\hline $\mathrm{W}_{41}$ & Stockpile \\
\hline $\mathrm{W}_{51}$ & Stockpile \\
\hline $\mathrm{W}_{61}$ & Wastewater \\
\hline $\mathrm{W}_{71}$ & Wastewater \\
\hline $\mathrm{W}_{81}$ & Water vapor \\
\hline $\mathrm{P}_{91}$ & Fine tapioca \\
\hline
\end{tabular}

The process in Compartment I is whole cassava brought to the root peeler hopper. During the stripping and cleaning process, the root peeler rotates, resulting in friction between the walls of the root peeler and cassava, and friction between the cassava. This friction results in the erosion of the cassava skin. The peeled cassava is then flowed to the washer (still in Compartment I). Washing is done using a washing tub equipped with a propeller arrangement. The propeller rotates so that the friction/thrust forces make the cassava washed and continuously move it to the cassava carrier screw to the next stage.

The next stage (Compartment II) is the cutting and crushing phase which aims to reduce the size of cassava tubers before the process of dissolution (Compartment III). The tool used is chopper. At the stage of dissolution (Compartment III) using a rasper, which is a rotating cylinder with saw blades.

Extraction is the stage of separating starch components from non starch components such as fiber. The working principle of the extraction process is to separate the starch suspension from cassava pulp with the help of a filter and centrifugal force. Extraction is divided into two parts, namely pulp extraction (Compartment IV) and milk extraction (Compartment V). The separation step (Compartment VI) aims to precipitate the starch suspension and separate it with water and impurities which may still be carried after the extraction process as well as non-starch components 
such as protein and fat. The tool used is separator. This tool is precipitating the starch suspension based on its specific gravity of the help of centrifugal force. The process of reducing water content (Compartment VII) is carried out using a Dewatering Centrifuge (DC). The working principle is to separate free water from the material based on particle size of the help of centrifugal force and filter cloth to produce wet starch.

The drying process (Compartment VIII) is carried out using a flash dryer, which is a chimney equipped with a blower at one end as an air suction, heat exchanger (steam or oil) for air heating, input of wet starch, and cyclone to separate air with tapioca. The drying medium used is heated air. The drying temperature ranges from $190^{\circ} \mathrm{C}-210^{\circ} \mathrm{C}$. Tapioca which has dried then sieved on a shiver with 80 mesh sieve sizes. The sieving machine uses a vibration and vertical movement system to separate fine tapioca with crust. The crust is a dry starch that does not pass through the 80 mesh sieve.

\section{The Equations}

The equation needed to solve the problem is equal to the number of dependent variables, namely 16 equations. One mass balance equation can be made from each compartment to obtain 8 equations. The remaining 8 equations were made as efficiency equations.

\section{Mass Balance Equations}

\begin{tabular}{|c|c|c|}
\hline Compartment I & $: \mathrm{I}_{11}+\mathrm{I}_{12}-\mathrm{X}_{1}-\mathrm{W}_{11}-\mathrm{W}_{12}$ & $=0$ \\
\hline Compartment II & $: \mathrm{X}_{1}+\mathrm{X}_{21}-\mathrm{X}_{2}$ & $=0$ \\
\hline Compartment III & $: X_{2}-X_{21}-X_{3}$ & $=0$. \\
\hline Compartment IV & $: \mathrm{I}_{41}+\mathrm{X}_{3}-\mathrm{X}_{4}-\mathrm{W}_{41}$ & $\ldots(4)$ \\
\hline Compartment V & $: \mathrm{I}_{51}+\mathrm{X}_{4}-\mathrm{X}_{5}-\mathrm{W}_{51}$ & $\ldots(5)$ \\
\hline CompartmentVI & $: \mathrm{I}_{61}+\mathrm{X}_{5}-\mathrm{X}_{6}-\mathrm{W}_{61}$ & $=0$ \\
\hline Compartment VII & $: \mathrm{X}_{6}-\mathrm{X}_{7}-\mathrm{W}_{71}$ & $=0$ \\
\hline Compartment VIII & $: \mathrm{X}_{7}-\mathrm{P}_{91}-\mathrm{W}_{81}$ & $=0$ \\
\hline
\end{tabular}

\section{Efficiency Equations}

Peeled cassava production $\left(\mathrm{a}_{1}\right)$

$\mathrm{a}_{1}=\frac{\mathrm{X}_{1}}{\mathrm{I}_{11}}=\frac{\text { Peeled Cassava }}{\text { Cassava Tuber }}$

Peel waste resulting from stripping cassava is 12\% (Chavalparit and Ongwandee 2009; Kosugi et al. 2008; Grace 1997). This means $88 \%$ is peeled cassava; the value of $\mathrm{a}_{1}$ is 0.88 .

Peel waste volume $\left(\mathrm{a}_{2}\right)$

$\mathrm{a}_{2}=\frac{\mathrm{W}_{11}}{\mathrm{I}_{11}+\mathrm{I}_{12}}=\frac{\text { Peel }}{\text { Cassava Tuber }+ \text { Added Water }}$

According to Chavalparit and Ongwandee (2009), cassava peel generated was 0.38 tons from 5.4 tons of water input and 4.21 tons of cassava input. The percentage of cassava peel generated is $4 \%$ of the water and cassava input; the value of $\mathrm{a}_{2}$ is 0.04 .

Grated cassava production $\left(\mathrm{a}_{3}\right)$

$\mathrm{a}_{3}=\frac{\mathrm{X}_{3}}{\mathrm{X}_{2}}=\frac{\text { Grated Cassava }}{\text { Cassava Chip }}$

According to Fauzi et al. (2008), the process of cassava stripping contained the remains of scattered cassava which is $2 \mathrm{~kg}$ out of a total of $80 \mathrm{~kg}$ of the cutting process. The percentage of grated cassava is $98 \%$ of chopped cassava, the value of $\mathrm{a}_{3}$ is 0.98 .

The first extraction process $\left(\mathrm{a}_{4}\right)$

$\mathrm{a}_{4}=\frac{\mathrm{X}_{4}}{\mathrm{X}_{3}+\mathrm{I}_{41}}=\frac{\text { Pulped Cassava }}{\text { Grated Cassava }+ \text { Added Water }}$ 
According to Sriroth et al. (2000), the cassava pulp produced by the $1^{\text {st }}$ extraction was 856.33 tons of $2,126.95$ tons of grated cassava and 1,362.18 of water input. The percentage of extraction of cassava in the first extraction is $25 \%$ of grated cassava plus water input; the value of $a_{5}$ is 0.25 .

The second extraction process $\left(\mathrm{a}_{5}\right)$

$\mathrm{a}_{5}=\frac{\mathrm{X}_{5}}{\mathrm{X}_{4}+\mathrm{I}_{51}}=\frac{\text { Cassava Slurry of Second Extraction }}{\text { Grated Cassava }+ \text { Added Water }}$

According to Srinophakun et al. (2000), cassava slurry production of the $2^{\text {nd }}$ extraction was 16.12 tons from cassava pulp production of the $1^{\text {st }}$ extraction of 52.49 tonnes and water input of 1.65 tons. The percentage of cassava slurry in the second extraction station was $28 \%$ of the cassava pulp produced by the $1^{\text {st }}$ extraction plus water input, the vaue of $a_{5}$ is 0.28 .

Separation process $\left(\mathrm{a}_{6}\right)$

$$
\mathrm{a}_{6}=\frac{\mathrm{X}_{6}}{\mathrm{X}_{5}+\mathrm{I}_{61}}=\frac{\text { Separated Cassava Slurry }}{\text { Cassava Slurry of second Ectraction }+ \text { Added Water }}
$$

According to Sriroth et al. (2000), cassava slurry results from the separation is 592.37 ton from 2,025.43 ton of the cassava in the second extraction and water input of 260 tons. The percentage of cassava slurry resulting from the separation was $26 \%$ from the $2^{\text {nd }}$ extraction plus water input; the value of $a_{7}$ is 0.26 .

Dewatering process $\left(\mathrm{a}_{7}\right)$

$\mathrm{a}_{7}=\frac{\mathrm{X}_{7}}{\mathrm{X}_{6}}=\frac{\text { Wet Starch }}{\text { Separated Cassava Slurry }}$

The resulting wet starch was 380.24 ton out of 592.37 ton separating cassava pulp. The percentage of wet starch is $64 \%$ of the separated cassava pulp (Sriroth et al. 2000), the value of $\mathrm{a}_{8}$ is 0.64 .

Tapioca production $\left(\mathrm{a}_{8}\right)$

$\mathrm{a}_{8}=\frac{\mathrm{P}_{91}}{\mathrm{X}_{7}}=\frac{\text { Tapioca }}{\text { Wet Tapioca }}$

Tapioca produced was 245.29 ton of wet starch of 380.24 ton. The percentage of tapioca produced is $64 \%$ (Chavalparit and Ongwandee 2009; Srinophakun et al. 2000; Sriroth 2000), the value of $\mathrm{a}_{6}$ is 0.64 . Tabel 3 summarises the value of the equation efficiency.

\section{Result and Discussion:- \\ Mass Balance Model}

The mass balance model was developed following compartments and sub-compartments that describe machines/processes at each station, so that the details of mass changes will be seen more clearly and detail. The model calculates a yield of $32 \%$ which is higher than Garbalet al. (2012) and Rahmatulet al. (2013) as much as 20$30 \%$ and larger than factory actual data. The yield difference is caused by a more detailed and complex mass flow, so the model is more accurate and consistent. This detailed calculation reduces output that is not identified, so that mass flow has a system efficiency of $100 \%$. This better yield is due to the looping system on the remaining scattered cassava $\left(\mathrm{W}_{21}\right)$ in Compartment 3, which is brought back to the cutting process (Compartment 2). At this level of yielding the amount of stockpile produced is $53.5 \%$. The mass flows of tapioca production is shown at Figure 3.

Table 3:-Eficiency factor values

\begin{tabular}{|c|c|l|}
\hline Symbol & Value & References \\
\hline $\mathrm{a}_{1}$ & 0.90 & Chavalparit dan Ongwandee (2009);Kosugiet al. (2008); Grace (1977) \\
\hline $\mathrm{a}_{2}$ & 0.04 & Chavalparit dan Ongwandee (2009) \\
\hline $\mathrm{a}_{3}$ & 0.98 & Fauzi et al. $(2008)$ \\
\hline $\mathrm{a}_{4}$ & 0.20 & Srinophakun et al. $(2000)$ \\
\hline $\mathrm{a}_{5}$ & 0.28 & Srinophakun et al. $(2000)$ \\
\hline $\mathrm{a}_{6}$ & 0.26 & Sriroth et al. $(2000)$ \\
\hline $\mathrm{a}_{7}$ & 0.64 & Sriroth et al. $(2000)$ \\
\hline $\mathrm{a}_{8}$ & 0.64 & Chavalparit dan Ongwandee (2009); Srinophakun et al. (2000); Sriroth et al. (2000) \\
\hline
\end{tabular}




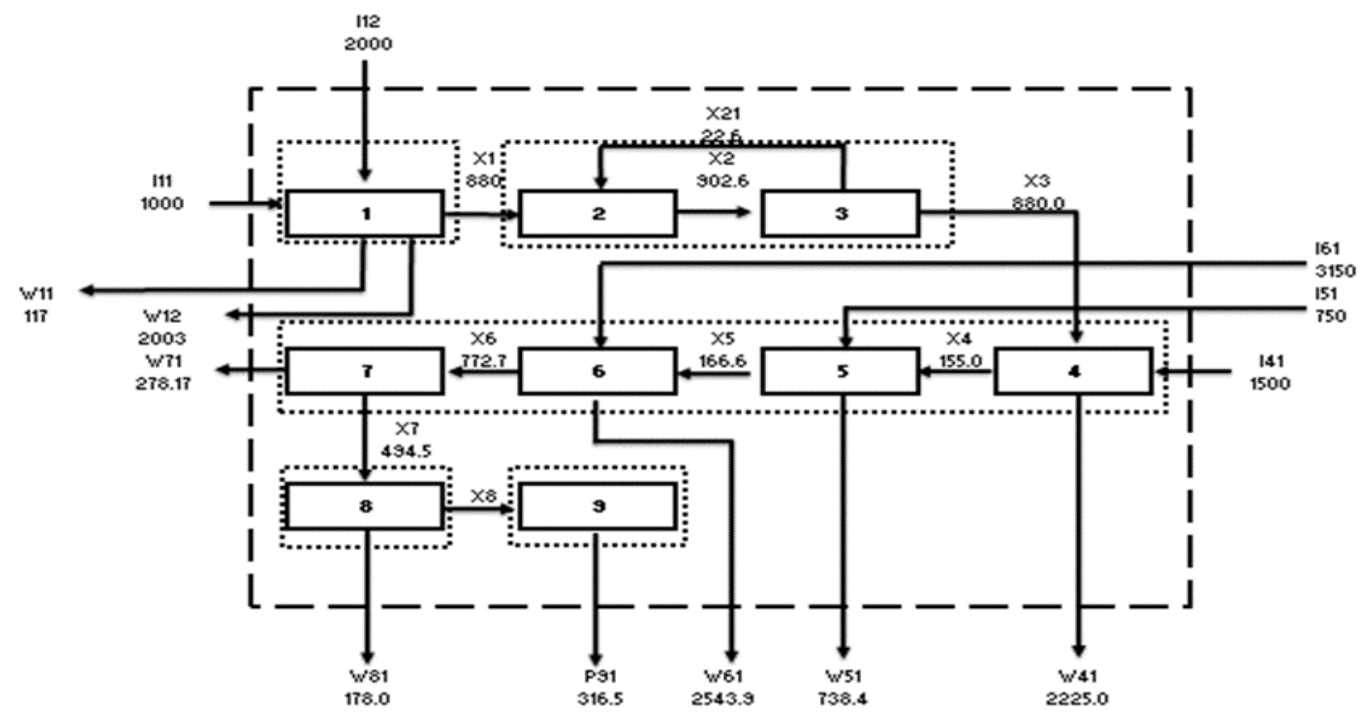

Figure 3;-Material flows of tapioca production - the model output (symbols description in Table 2)

\section{Energy and Water Potency of the Wastes}

Stockpile, cassava peel, wastewater and evaporated water are the outputs of the cassava processing into tapioca with a considerable amount. The biomass (except water) contains energy so that they can be used as energy sources. Most tapioca factories in Indonesia only use stockpile and peels as a mixture of animal feed or processed into ethanol and biogas (Yu and Tao 2008; Okudoh 2014).

Stockpile (fiber) can be used as an alternative energy source because it contains high carbohydrate and fiber compounds. Composition of stockpile constituent consists of carbohydrates $(68.30-67.93 \%)$, protein (1.70 $1.45 \%)$, fats $(0.22-0.30 \%)$, fiber $(9.42-10.54 \%)$ and water $(19.70-20.20 \%)$ (Nurhasanah and Pramuddyanto 1993). It contains 50-60\% starch on a dry basis and 60-70\% moisture content (Panichnumsin et al. 2010; Sriroth et al. 2000; Pandey et al. 2000). According to Weerachanchai et al. (2011) the calories contained in stockpile is $15 \mathrm{MJ}$ per $\mathrm{kg}$, whereas according to Tung and Steinbrecht (2008) is $15.9 \mathrm{MJ}$ per $\mathrm{kg}$.

According to Balogun and Bawa (1997), cassava peels have a calorie of $19.1 \mathrm{MJ} / \mathrm{kg}$. The chemical and nutritional components of cassava peels per $100 \mathrm{~g}$ are $8.11 \mathrm{~g}$ protein, $15.2 \mathrm{~g}$ crude fiber, $0.22 \mathrm{~g}$ pectin, $1.29 \mathrm{~g}$ fat and $0.63 \mathrm{~g}$ calcium (Rukmana 1997). High calorific value of stockpile and cassava peel can be burned on the steam boiler. The efficiency of using stockpile for furnace and boiler equipment is around 76.83\% (Bora and Nakkeeran 2014).

A Boiler generates steam at very high pressures and temperature. High pressure steam is used to drive the turbine in the generator so that it can generate electricity. Wolowicz et al. (2012) stated that the efficiency of electrical and thermal energy conversion using steam turbine co-generation condensation could reach $43.5 \%$. The electrical energy produced is used to supply the electricity needs of the tapioca production process. Calculation of potential byproducts can be seen in Table 4 using equation: Energy potential $(\mathrm{kcal})=$ Mass $\mathrm{x}$ Calorific value.

Table 4:-Calorific value of tapioca wastes (1,000 ton cassava/day)

\begin{tabular}{|l|r|r|r|l|}
\hline Wastes & Mass (ton) & Calorific Value (kcal/kg) & Energy Potency (kcal) & References \\
\hline Cassava peel & 117 & 707 & $82,719,000$ & Devendra 1977 \\
\hline Stockpile (dry basis) & 533.4 & 2,484 & $1,324,995,408$ & Khempaka et al. 2009 \\
\hline Total & & & $1,407,714,408$ & \\
\hline
\end{tabular}

In the tapioca industry, electricity is needed for the process of producing tapioca. This process consists of cutting, cassava slurry separation process and dewatering process. The closed system model in the tapioca industry is an expression of self-reliance to meet energy without external input other than raw material and water input. Energy obtained from by-products is reused to meet electrical energy needs during the production process. By-products are converted into heat energy by the steam turbine system. Stockpile and peel are burned directly to produce steam 
used in turbines to produce electrical energy. In theoretical calculations, the electrical energy produced from stockpile and peel is $11,734.82 \mathrm{kWh}$ per day (Table 5).

In tapioca production, water is one of the important input materials. Mulyanto and Titiresmi (2008) stated that in the process of producing tapioca needs $7 \mathrm{~m}^{3}$ of water per 1 ton of cassava. Another opinion, Mai (2006) stated that the water requirement is $10-30 \mathrm{~m}^{3}$, a more water used in the washing process will improve the quality of flour produced. The water needs can be reduced by reprocessing wastewater during the production process.

In addition to producing stockpiles and peels, the tapioca production generates wastewater containing nutrients (nitrogen, carbon, phosphorus, potassium, calcium, magnesium, sulfur, zinc, manganese, copper, iron and sodium) (Kurniawan 2009, Ubalua 2007 ) so that if it is discharged into public waters without processing, it will cause water pollution, which in turn will endanger aquatic biota and cause unpleasant odor. To minimize the risk of water pollution, many tapioca industries apply Wastewater Treatment Plant (WWTP).

Biogas production technology has been applied to tapioca wastewater treatment plants. Wastewater treatment for a capacity of $150 \mathrm{~m}^{3}$ produces $485.4 \mathrm{~m}^{3}$ of biogas per day. It can be assumed that every $1 \mathrm{~m}^{3}$ of wastewater produces $3.2 \mathrm{~m}^{3}$ of biogas. From the results of biogas analysis, it is estimated that every $1 \mathrm{~m}^{3}$ of wastewater can produce 1.88 $\mathrm{m}^{3}$ of methane gas (Wintolo and Isdiyanto 2011). Based on the results of measurements of gas emissions in the anaerobic pond of tapioca industry shows that every one ton of cassava can produce $24.4 \mathrm{~m}^{3}$ of biogas or 14.6-15.8 $\mathrm{m}^{3}(60-70 \%)$ of methane per ton of cassava and has a calorific value of $5,200-5,900 \mathrm{kcal} / \mathrm{m}^{3}$ (Adelekan and Bamgboye 2009, Haryati 2006, Indarto 2010).

The by-products in the form wastewater can generate electrical energy of 22,774 $\mathrm{kWh}$ (Table 6). However, the efficiency of gas generator is 35\% (Wibowo 2016). Therefore, the electrical energy that can be produced from wastewater is $7,971 \mathrm{kWh}$. When added to the energy surplus from stockpile and cassava peels, a surplus of $19,705.84 \mathrm{kWh}$ per day is obtained. 
Table 5:-Biomass to electrical energy conversion (factory capacity 1,000 ton cassava /day)

\begin{tabular}{|c|c|c|}
\hline Parameter & Units & Total \\
\hline Stockpile (dry basis) & ton/day & 533.4 \\
\hline Cassava peel & ton/day & 117 \\
\hline \multicolumn{3}{|l|}{ Energy Content } \\
\hline Stockpile & $\mathrm{kcal} / \mathrm{kg}$ & $2,484^{\mathrm{b}}$ \\
\hline Cassava peel & $\mathrm{kcal} / \mathrm{kg}$ & $707^{\mathrm{a}}$ \\
\hline \multicolumn{3}{|l|}{ Total Energy } \\
\hline Stockpile & kcal & $1,324,995,408$ \\
\hline Cassava peel & kcal & $82,719,000$ \\
\hline Total & kcal & $1,407,714,408$ \\
\hline \multicolumn{3}{|l|}{ Heat requirement } \\
\hline $1 \mathrm{~kg}$ steam at $30 \mathrm{Bar} \&$ saturated temperature & $\mathrm{kcal} / \mathrm{kg}$ & 669.93 \\
\hline \multicolumn{3}{|l|}{ Steam generated } \\
\hline Steam from stock pile energy & $\mathrm{kg} / \mathrm{day}$ & $1,977,811$ \\
\hline Steam from cassava peel energy & $\mathrm{kg} /$ day & 123,474 \\
\hline Total & $\mathrm{kg} /$ day & $2,101,285$ \\
\hline Average boiler efficiency & $\%$ & $76.83^{\mathrm{c}}$ \\
\hline \multicolumn{3}{|l|}{ Actual steam } \\
\hline From stock pile energy & $\mathrm{kg} /$ day & $1,519,553$ \\
\hline From cassava peel energy & $\mathrm{kg} /$ day & 94,865 \\
\hline \multirow[t]{2}{*}{ Total generated steam } & $\mathrm{kg} /$ day & $1,614,418$ \\
\hline & $\mathrm{kg} / \mathrm{s}$ & 18.7 \\
\hline \multicolumn{3}{|l|}{ Power Generation } \\
\hline Steam turbine conversion & $\mathrm{kg} / \mathrm{s}$ & $61^{\mathrm{d}}$ \\
\hline Turbine efficiency & $\%$ & $43.5^{\mathrm{d}}$ \\
\hline Turbine power & $\mathrm{kWh}$ & $833,000^{\mathrm{d}}$ \\
\hline Electricity output & $\mathrm{kW} / \mathrm{day}$ & 110,996 \\
\hline Electricity requirement & $\mathrm{kW} / \mathrm{day}$ & $99,261^{\mathrm{e}}$ \\
\hline Surplus & $\mathrm{kW} / \mathrm{day}$ & 11,735 \\
\hline
\end{tabular}

${ }^{\mathrm{a}}$ Balogun dan Bawa 1997; ${ }^{\mathrm{b}}$ Tung dan Steinbrecht (2008)

${ }^{\mathrm{c}}$ Bora dan Nakkeeran (2014); ${ }^{\mathrm{d}}$ Wolowicz et al.(2012)

e Jekayinfa dan Olajide (2007)

Table 6:-Conversion of wastewater to electrical generation

\begin{tabular}{|c|c|c|c|c|}
\hline Waste & Mass (ton) ${ }^{\mathrm{a}}$ & Biogas Potency $\left(\mathrm{m}^{3}\right)$ & Methane Potency $\left(\mathrm{m}^{3}\right)$ & Electrical Power (kW) \\
\hline Wastewater & 4,825 & 15,440 & 9,110 & 7,971 \\
\hline
\end{tabular}

Capacity of factory is 1,000 ton cassava per day

In addition to wastewater, processing cassava into tapioca produces water favour from dewatering station and pressing stockpile which when condensed can produce water. The water can be reused to meet the needs in processing cassava into tapioca. The source of water favour and its mass are presented in Table 7.

Table 7:-Evaporated water in tapioca production

\begin{tabular}{|l|l|}
\hline Source & Mass (ton) \\
\hline Stockpile pressing & 2,074 \\
\hline Dewatering & 278 \\
\hline Total & 2,353 \\
\hline
\end{tabular}

Note: factory capacity of 1,000 ton cassava/day

According to Table 7, the total of evaporated water only $32 \%$ meets the water demand of the industry from a total of 7,400 ton of water. If 2,353 ton of water were channeled into the extraction station, which requires 2,250 tons of water, then there were an excess of 103 ton of water that can be channeled into the separation station. Utilization of 
evaporated water requires a cool and filtering process to be clean water raw material and does not affect the tapioca production process (Figure 4).

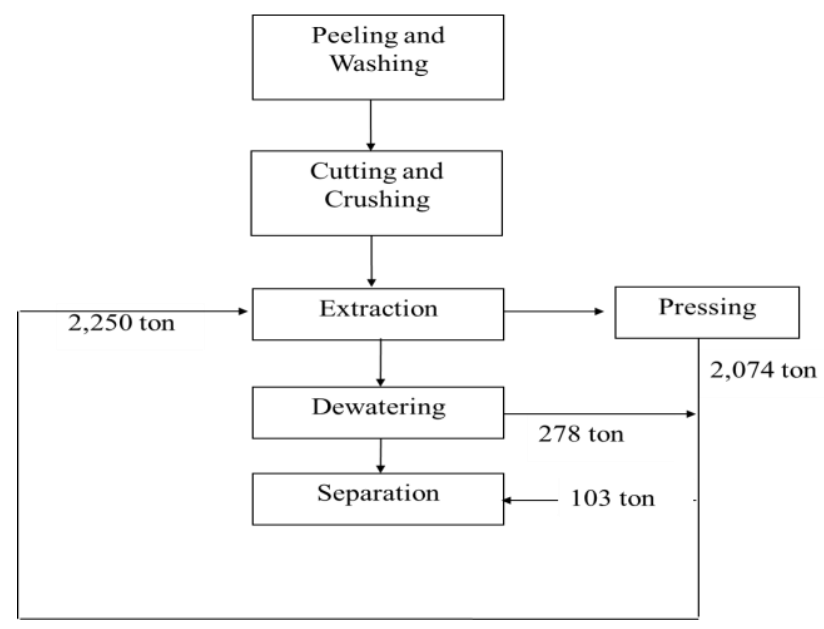

Figure 4:-Water reuse diagram

\section{Closed Production Sytem of Tapioca Industry}

The tapioca production system produces by-products in the form of water vapor, stockpile, wastewater, and cassava peel. The by-products which still contain energy such as peel and stockpile can be reused as energy sources, but not all by-products can be reused due to high water content.

Water vapor produced from the drying process is collected by the condenser to produce water which can be reused as water input in the extraction and separation processes. Wastewater generated from the washing process, separation and dewatering can be reused to generate biogas that is converted into electrical energy. A closed production system of tapioca industry is shown in Figure 5, where all by-products are reused.

\section{Conclusion and Recommendation:-}

\section{Conclusion}

The mass balance model can describe the real situation in tapioca factories. The results of water vapor can be reused as a water source at extraction and separation stations. Energy potential is obtained from wastes including peel, stockpile and wastewater. In tapioca industry with a capacity of 1,000 tons of cassava per day, it produces 117 ton of cassava peel, 533.4 ton of stockpile, and 4,825 ton of wastewater. Stockpile and peel can produce electrical energy equal to $110,996 \mathrm{kWh}$ per day. Wastewater can produce electrical energy of 7,971 kWh per day. The plant's electricity needs are 99,261 kWh per day, so the tapioca industry can be independent of energy and there is still an electricity surplus of 19,706 kWh per day. The independent energy production model can be developed into tapioca industrial production systems that are energy independent and therefore can be developed into a closed production systems industry.

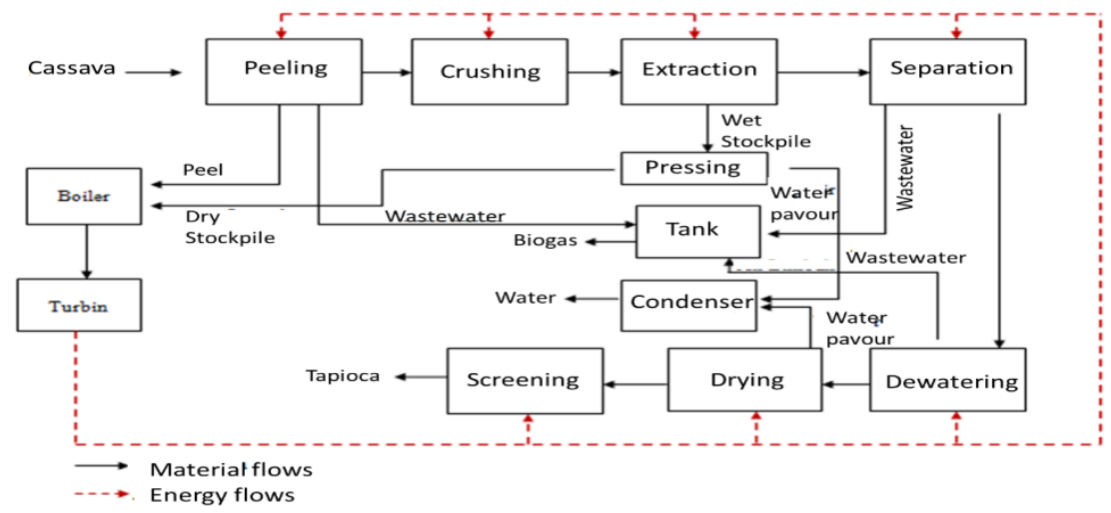

Figure 5:-A closed production system of tapioca industry 


\section{Recommendation:-}

Further research in implementing this system needs to be done to adjust energy needs with various process technologies. This adjustment needs to be done because each industry has different machine operations and specifications so that energy requirements will also be different.

\section{References:-}

1. Adelekan BA, Bamgboye AI. 2009. Comparison of Biogas Productivity of Cassava Peels Mixed in Selected Ratios with Major Livestock Waste Types. African Journal of Agricultural Research, 4(7):571-577.

2. Balagopalan C, Ray RC, Sheriff JT, Rajalakshmy L. 1994. Biotechnology for the Value Addition of Waste Waters and Residues from Cassava Processing Industries. Bogor (ID): Proceedings of the Second International Scientific Meeting of the Cassava Biotechnology Network.

3. Balogun TF, Bawa GS. 1997. Cassava Peels in the Diet of Young Pigs in Nigeria. Journal of Trop. Anim. Hlth Prod, 4 (1997): 209-215.

4. Bantacut, T. and Pasaribu, H. 2015. Aliran tertutup massa dan potensi mandiri energi pada produksi CPO (Closed mass flows and energy self sufficiency in CPO production). Jurnal Teknologi Industri Pertanian, 25(3): 215-226.

5. Bantacut T, Novitasari D. 2016. Energy and Water Self-sufficiency Assessment of the White Sugar Production Process in Indonesia Using a Complex Mass Balance Model. Journal of Cleaner Production, 126 (2016): 1-15.

6. Bantacut, T. and Nurdiansyah, M. 2017. A closed model of production system for energy self-sufficiency rice mill . Journal of Energy Technologies and Policy, 7(7): 34-48.

7. Bantacut, T. and Zuriel, A. 2018. A closed model of production system for independent energy in corn flours industry. International Journal of Advance Research, 6(4): 173-186.

8. Bora MK, Nakkeeran S. 2014. Performance Analysis from the Efficiency Estimation of Coal Fired Boiler. Internation J Advan Resear, 2(5): 561-574.

9. Cengel YA, Boles MA. 2002. Thermodynamics: An Engineering Approach 4th Edition In SI Units. Singapore (SI): McGraw-Hill.

10. Chavalparit O, Ongwandee M. 2009. Clean technology for the tapioca starch industry in Thailand. Journal of Cleaner Production 17: 105-110.

11. Devendra C. 1977. Cassava as a Feed Source for Ruminants. In: Proceedings of a workshop held at the University of Guelph. 107

12. Fauzi AM, Rahmawakhida A, Hidetoshi Y. 2008. Study on Cleaner Production Strategy in the Small Scale Tapioca Industry: a Case Study in Kelurahan Ciluar, North Bogor Sub-District. J. Tek. Ind. Pert., 18(2) :60-65.

13. Garba MU, Mohammed A, Etim ED. 2012. A Kinetic Study of the Enzymatic Hydrolysis of Cassava Starch. Journal of Science and Engineering Investigation, 1(11): 65-70.

14. Grace MR. 1977. Cassava Processing.Roma (IT): Food and Agriculture Organitation of The United Nation.

15. Haryati T. 2006. Biogas: Limbah Peternakan yang Menjadi Sumber Energi Alternatif. Journal of Animal and Veterinary Sciences, 16(3): 160-169.

16. Hermiati E, Mangunwidjaja D, Sunarti TC, Suparno O, Prasetya B. 2012. Potential Utilization of Cassava Pulp for Ethanol Production in Indonesia. Journal of Scientific Research and Essay, 7(2): 100-106.

17. Indarto KE. 2010. Produksi Biogas Limbah Cair Industri Tapioka Melalui Peningkatan Suhu dan Penambahan Urea pada Perombakan Anaerob [Skripsi]. Surakarta (ID) : Universitas Sebelas Maret.

18. Jekayinfa SO, Olajide JO. 2007. Analysis of Energy Usage in the Production of Three Selected Cassava-Based Foods in Nigeria. Journal of Food Engineering, 82: 217-226.

19. Khempaka S, Molee W, Guillaume M. 2009. Dried Cassava Pulp as an Alternative Feedstuff for Broilers: Effect on Growth Performance, Carcass Traits, Digestive Organs, and Nutrient Digestibility. Journal of Poultry Science, 18: 487- 493.

20. Kosugi A, Akihiko Kondo, Mitsuyoshi Ueda. 2008. Production of ethanol from cassava pulp via fermentation with a surface engineered yeast strain displaying glucoamylase. Department of Chemical Science and Engineering, Faculty of Engineering, Kobe University.

21. Kurniawan MFC. 2009. Pemanfaatan Limbah Cair Tapioka Untuk Penghasil Biogas Skala Laboratorium [Tesis]. Bogor (ID): Institut Pertanian Bogor.

22. Mai HNP. 2006. Integrated Treatment of Tapioca Processing Industrial Wastewater Based on Environmental Bio-Technology [Dissertationi]. Netherlands (NL): Wageningen University.

23. Mareta I. 2010. Penyiapan Bahan Baku Dalam Proses Fermentasi Fase Cair Asam Sitrat Melalui Proses Hidrolisa Ampas Singkong [Skripsi]. Semarang (ID): Universitas Diponegoro. 
24. Mulyanto A, Titiresmi. 2008. Implementation of Anaerobic Process on Wastewater from Tapioca Starch Industries. Institute for Environmental Technology, Agency for the Assessment and Application of Technology Building, Puspitek Serpong, Tangerang. Indonesia.

25. Muryani, Suharni S, Sulastri, Sugesti W. 2012. Pemanfaatan Limbah Padat Tapioka sebagai Industri Rumah Tangga Perdesaan. Jurnal Kelitbangan, 1(6): 63-72.

26. Nurhasanah, Pramuddyanto B. 1993. Penanganan Limbah Cair Indusrti Kecil Tapioka. Jakarta (ID): Yayasan Bina Karta Lestari.

27. Okudoh V, Trois C, Workneh T, Schmidt S. 2014. The potential of cassava biomass and applicable technologies for sustainable biogas production in South Africa: A review. Journal of Renewable and Sustainable Energy, 39: 1035-1052.

28. Panichnumsin P, Nopharatana A, Ahring B, Chaiprasert P. 2010. Production of methane by co-digestion of cassava pulp with various concentrations of pig manure. Journal of Biomass and Bioenergy, 34: 1117-1124.

29. Pandey A, Sccol CR, Nigam P, Soccol VT, Vandenberghe LPS, Mohan R. 2000. Biotechnological potential of agro-industrial residues II: cassava bagasse. Bioresour. Technol., 74(2000): 81-87.

30. Pramana D. 2014.Kajian Energi Proses Pengolahan Industri Tapioka Rakyat Skala Menengah [Skripsi]. Lampung (ID): Universitas Lampung.

31. Rahmatul R, Nurrokhim A, Soewarno N, Nurkhamidah S. 2013. Produksi Biogas Dari Limbah Cair Industri Tepung Tapioka Dengan Reaktor Anaerobik 3.000 Liter Berdistributor. Jurnal Teknik Pomits., 2 (1): 1-5.

32. Rukmana, R. 1997. Ubi Jalar Budidaya dan Pasca panen. Yogyakarta (ID): Kanisius.

33. Maharani CND, Lestari DAH, Kasymir E. 2013. Analisis Nilai Tambah dan Kelayakan Usaha Pengolahan Limbah Padat Ubi Kayu (Onggok) Di Kecamatan Pekalongan Kabupaten Lampung Timur. Journal of Agribusiness Science, 1(4): 284-290.

34. Srinophakun T, Suriyapraphadilok U, Tia S. 2000. Water-Wastewater Management of Tapioca Starch Manufacturing Using Optimization Technique. Journal of Science, 26: 56-57.

35. Sriroth K, Piyachomkwan K, Wanlapatit Sdan Oates C.G. 2000. Cassava Starch Technology: The Thai Experience. Journal of Starch Starke, 52 (2000): 439-449.

36. Tung ND, Steinbrecht D. 2008. Modeling a Combined Heat and Power Cogeneration System in Vietnam with a Fluidized Bed Combustor Burning Biomass. Agricultural Engineering International: the CIGR Ejournal. Manuscript EE 08 008. Vol10 (1): 1-22.

37. Ubalua AO. 2007. Cassava Wastes: Treatment Options and Value Addition Alternatives. African Journal of Biotechnology, 6 (18): 2065-2073.

38. Weerachanchai P, Tangsathitkulchai C, Tangsathitkul M. 2011. Characterization of Products from Slow Pyrolysis of Palm Kernel Cake and Cassava Pulp Residue. Korean J. Chem. Eng., 28 (12) : 2262- 2274.

39. Wibowo A. 2016. Analisis Potensi Pembangkit Listrik Biogas Berbasis Limbah Cair Pabrik Kelapa Sawit Studi Kasus PKS PT Intan Sejati Andalan, Riau. Jurnal Teknik., 5(2): 126-133.

40. Winarno FG, Fardiaz S, Fardiaz D, 1988. PengantarTeknologiPangan. Jakarta (ID): GramediaPustakaUtama.

41. Wintolo M, Isdiyanto R. 2011. Prospek Pemanfaatan Biogas dari Pengolahan Air Limbah Industri Tapioka. Jurnal Ketenagalistrikan dan Energi Terbaru, 10(2): 103-112.

42. Wolowicz M, Milewski J, Badyda K. 2012. Feedwater Repowering of 800 MW Supercritical Steam Power Plant. J Pow Technol., 92(2): 127-134.

43. Yu S, Tao J. 2008. Energy efficiency assessment by life cycle simulation of cassava-based fuel ethanol for automotive use in Chinese Guangxi context. Journal of Energy. 34: 22-31. 